\title{
METHODS USED BY MOTHERS TO HELP CHILDREN DURING SOLVING COGNITIVE PROBLEM TASKS: COMPARISON BETWEEN MOTHERS OF SECURELY AND INSECURELY ATTACHED PRESCHOOL CHILDREN
}

\author{
Lara CAKIĆ ${ }^{1}$, Ljubica MARJANOVIČ-UMEK ${ }^{2}$ \\ ${ }^{1}$ J.J. Strossmayer University of Osijek, Faculty of Education \\ Ulica cara Hadrijana 10, 31000 Osijek, Croatia \\ E-mail: 1cakic@foozos.hr \\ ${ }^{2}$ Department of Psychology, Faculty of Arts \\ University of Ljubljana
}

\begin{abstract}
Attachment is a permanent emotional bond activated in children by signals that they perceive as frightening, dangerous or stressful, while in the parents' attachment system of care, it is activated by the goal of satisfying children's needs. The aim of this research was to determine which strategies mothers use in their interaction with children, aged 5 to $7(\mathrm{~N}=80)$ during their cognitive problem solving. More specifically, the goal was to ascertain if there is a difference in the sensitivity to children's cognitive needs on the part of mothers of securely and mothers of insecurely attached children. Compared to mothers of insecurely attached children, mothers of securely attached children more often help their child by giving it appropriate instructions (scaffolding). Mothers of insecurely attached children, in situations when the child's solution is incorrect, more often help their children by giving them long explanations, regardless whether the child listens or understands what is been said (a monologue).
\end{abstract}

Key words: attachment, preschool children, mothers, social interactions, strategy use

\section{Introduction}

Integrating the results of research by Lorenz and Harlow and conclusions from the field of evolutionary biology, ethology and psychoanalysis, Bowlby (1969/82) developed the theory of attachment between children and mothers. In his theory, he defines attachment as a strong emotional bond with the object of attachment. This bond is characterized by closeness and proximity to the particular person, especially during times of threat and distress. Bowlby believes the attempt of getting close to a particular person to be a basic form of human behavior, which increases the probability of protection and survival. Parental behavior is organized and managed by a behavioral system of care and protection, and it is connected to the attachment behavior system of a child.

In 1969, Mary Ainsworth further elaborated on Bowlby's theory by drafting a method for evaluation of attachment (The Strange Situation) for children aged 12 to 20 months. In research using these techniques, children's reactions are described through two forms of behavior with the parent, which the author classifies as follows: securely attached children and insecurely attached children 
(anxious-ambivalent and anxious-avoidant). Main \& Solomon (1986) also developed guidelines for classification of a third insecurely attached form of behavior, and they named it disorganized/disorientated.

Later development of measures that use pictorial material and puppets, has enabled the evaluation of attachment for older children as well. In this research, we used the MCAST (The Manchester Child Attachment Story Task) techniques (Green, Stanley, Smith, \& Goldwyn, 2000).

According to the attachment theory, one of the parent's important roles is that the child's behavior, such as protection seeking and closeness (the role and goal of attachment for the child) changes into offering protection, comfort and care for the child (the role and goal for the parent). The parent's system of care is activated by internal and external signals associated with situations, which the parent perceives as frightening, dangerous or stressful for the child (George \& Solomon, 2008).

When this system is activated, the parent needs to decide how to behave. This behavior depends on the evaluation of information from different sources. One of the sources is the evaluation of the child's signal and the other is the parent's evaluation of the threat or danger. There are also situations when the parent's care system is activated while the child's system is not. For example, situations when the parent believes the child is in danger while child does not see the same situation as dangerous. In that case, the parent's behavior could be controlling or intrusive (George \& Solomon, 2008). Moreover, the parent is constantly required to accommodate each of the developmental stages of the child (Moss \& Dubois-Comtois, 2004).
Research results show that children classified as 'avoiding' have parents who reacted more often than the parents of securely attached children (Belsky, Rovine, \& Taylor, 1984). Insecure attachment is related to the mother's reactions, which are often inappropriate, intrusive and inconsistent with the child's signals. Appropriate and sensitive responses of the mother can be defined as a timely and mutually rewarding behavior (Nievar \& Becker, 2008).

Etzion-Carasso \& Oppenheim (2000) in their research prove that mothers of securely attached children respond to signals of asking for help when needed, leaving children enough opportunity for autonomy, while mothers of insecurely attached children do not offer help when it is needed.

Belsky, Rovine, \& Taylor (1984) believe that secure attachment is a result of not too much and not too little stimulation. The authors also claim that avoidant attachment could be a result of too much stimulation for the child, and ambivalent attachment a result of insufficient stimulation.

Research with participating mothers and children aged 3 to 5, shows that the mother's behavior, which contributes to peaceful interactions between mother and child, is associated with secure attachment of the child. The mother's control, her setting the boundaries and offering a secure base for the child, are also connected to secure attachment (Posada, Kaloustian, Richmond, \& Moreno, 2007).

In situations, when children are asked to solve cognitive problems, and they are not able to solve them, the reaction of the parent, solving the task together with the child, could be oriented towards modifying the child's emotion (child is anxious because of not being able to solve the task) and towards 
offering help in solving the cognitive problem (illustration and explanation of the problem), which will result in the modification of emotion.

It is of great importance to recognize the nature of the child's need, in order to adequately react to that need.

Ignjatović-Savić, Kovač-Cerović, Plut, \& Pešikan (1990) describe a case when a child tries to open a box of matches and starts showing signs of anxiety when it does not succeed. One mother takes a child into her arms, caresses it and finally calms it down; while the other mother takes part in the child's activity and manages to direct it to open the box, which calms the child down. Although both mothers are sensitive to signs of anxiety in the child and react to those signs, the first mother is not able to understand or neglects the fact that the child has a cognitive problem, and with her behavior she responds only to the child's affective needs, while the other mother responds both to the affective as well as cognitive needs of the child. These different kinds of behaviors of the mothers can be observed during motherchild interaction in situations when the child cannot solve a particular cognitive problem independently.

The mother's cooperation can also be observed in case of problems that child is able to solve independently. The mother then has the opportunity to ignore, praise or admire the child. An adequate response to child's needs in the cognitive domain is particularly visible in tasks where the child has a problem with solving a task and the mother recognizes its need. In other words, those tasks where a child cannot solve the problem alone but needs the help of a more competent person. According to Vygotsky (1977), a child will try to solve a problem using the best strategy it is able to use. If a task requires cognitive structures not yet developed in a child, the child will not be able to solve the task independently (Baucal, 2003). A child can solve a problem in the interaction with a parent or a person who does have the cognitive structure necessary for solving this problem. How do parents, most frequently a mother and later teachers, "organize" the interaction and communication? Series of research studies (Diaz, Neal, \& Vachio, 1991; Freund 1990; Garton, 1992; Rogoff, 1990; 1993; as cited in Vasta, Haith, \& Miller, 2005) have shown that parents are teaching their children by ,creating first step in scaffolding", by adapting the level of their help to child's level of abilities. A more competent person builds mental scaffolding, which the child relies on when obtaining new skills and knowledge. The use of scaffolding should bridge the gap between what the child is able to do by itself and what the child needs help with (Vizek Vidović, Vlahović-Štetić, Rijavec, \& Miljković, 2003).

During interaction with children, parents adapt their behavior according to the child's needs and characteristics, by the way they give explanations, by the amount of information they provide, the expressions they use, and repetitions. Beside these cognitive components of interaction, parents also use affective-motivational components (encouraging, stimulating to try again, to think things over).

The aim of this research is to determine the kinds of helping strategies used by mothers of securely and mothers of insecurely attached children, aged 5 to 7 , during the children's cognitive problem solving. Furthermore, the aim is to establish whether mothers differ in their ways of helping their children with regards to the form of the children's 
attachment. It is expected that mothers of insecurely attached children will more often provide inadequate help in comparison to the mothers of securely attached children.

\section{Method}

\section{Participants}

41 boys and 39 girls $(\mathrm{N}=80)$ aged 5 to 7 and their mothers $(\mathrm{N}=80)$ participated in the research. The average age of the children is 70.4 months (from 60 to 84 months). The average age of the mothers is 35 (from 24 to 44 years of age). All the children were attending one of the kindergartens in the city of Osijek. In terms of education, 57 mothers have finished high school, and 23 have a university degree. Mothers were informed about the research and they gave a written informed consent to participate.

\section{Measuring Instruments}

MCAST (Manchester Child Attachment Story Task), (Green, Stanley, Smith, \& Goldwyn, 2000)

MCAST is a semi-structured technique for assessment of children's attachment aged 5 to 7. For the assessment of the children's attachment, playing with a doll is used. Beside the doll, a wooden house with an open front side, with four rooms with furniture (kitchen, living room, bedroom and nursery), is also used. The technique consists of five tales, which the child has to finish. The child is first asked to choose one doll to represent $\mathrm{him} / \mathrm{her}$, and one doll to represent the mother. Then the researcher leads the child into the first tale and asks the child to continue the tale in a way as to play out and say what is going on in the tale. The technique is introduced to the child through the first tale, which is neutral. The other four tales are descriptions of situations in which the doll representing the child has been put into unpleasant situations (night mare, injury by fall, bellyaches and a situation when a child is lost in a crowd), while the second doll that represents the mother is nearby, but not in the same room. The researcher induces excitement and discomfort by presenting the tales, and afterwards asks the child to show and tell what happens next. It is expected that the child will present his/her attachment quality during the sequel, due to the induced discomfort. The researcher also encourages the child by asking what happens next. When the child finishes the story, the researcher asks additional questions concerning emotions and reflections of the doll-child and doll-mother relationship. After all the stories are finished, the child is given instruction to arrange the house as he/she wishes and play out something he/she loves doing. This reduces the level of discomfort induced by the stories. This part of the research is not recorded. The technique lasts for approximately 15 minutes, and the deviations in duration depend on the child, on the amount of information the child gives (through play and story-telling) as well as on the breaks the child takes. The whole procedure is recorded by camera from an angle where the whole house and child can be seen.

The recorded material is coded afterwards. The time, necessary for coding of the recorded material for each child, is around 2 hours. The criteria, used for assessing the attachment quality, are derived from the techniques for the assessment of attachment in adults (Adult Attachment Interview, George, Kaplan, \& Main, 1986) and children (The 
Strange Situation, Ainsworth, 1969). The criteria for coding involves assessment of behavior connected to attachment (i.e., searching for closeness and strategy of reducing discomfort), coherence of story, disorganized phenomena (chaos, absence of dominant strategy, incoherence of story, bizarreness) and the child's awareness of the states the story characters are in. Based on these data, attachment quality for each story is obtained, and the result consists of a combination of these 4 data.

The second coder codes 20 arbitrary selected recordings. For the adjustment of coders for attachment quality, the Cohen kappa coefficient is 78 .

Authors of the MCST technique (Green, Stanley, Smith, \& Goldwyn, 2000) cite that for the adjustment of different coders for attachment quality, the Cohen kappa coefficient is 74 .

Video recordings of mothers and children during the problem solving

In order to establish the strategies and ways of communication mothers use with their children during problem solving tasks, the mothers and the children are video recorded during task solving of a nonverbal test, in order to observe the children's ability in logical concluding Coloured Progressive Matrices (Raven, 1956; as cited in Raven, Raven, \& Court, 1999). The test is designed for children aged 5 to 11.23 tasks were being solved (the entire test consists of 36 tasks). In all tasks the child is expected to choose among the given answers ( 6 drawings) the one answer, which completes the drawing with one missing part. The solving of the tasks requires recognition of relations in abstract visual representations.
Mothers received instructions to help a child when they want and in the way they want.

In order to recognize the way mothers communicate with children, a category system of ways in which social interaction and communication is initialized, has been devised. In devising the category system the observed mothers' behaviors are as follows:

- Mother's verbal reactions at the beginning of each task

- Mother's verbal reactions when child solves task correctly

- Mother's verbal reactions after child's incorrect answer

- Mother's verbal reactions to the child's correct answer after child first answers incorrectly

Two coders (psychologists) checked 10 randomly chosen recordings and noted all mother's verbal reactions.

Based on mother's verbal reactions these categories are determined:

A Mother's verbal reactions at the beginning of each task:

a1 - no verbal reactions

a2 - saying to child that it needs to solve the task (motivating, encouraging)

a3 - warning the child to be careful (i.e., look carefully, don't hurry)

a4 - gives only one correct instruction (creates the first step in scaffolding)

a5 -gives a long explanation how to solve the task without observing whether the child listens or understands what has been said (monologue)

a6 - describes solution (leads child to give the right answer, i.e. covers drawings and helps child guess)

$B$ Mother's verbal reactions after child solves task correctly (correct answer is not preceded by incorrect answer): 
b1- no verbal reactions

b2 - confirmation that child correctly solved the task (i.e., yes, good)

b3 - praise (i.e., well done, great)

b4 - more praise (bravo, bravo, great)

b5 - asking or giving extra explanation about the solution (i.e., why do you think this one is correct?)

$C$ Mother's verbal reactions after child's incorrect answer:

c1- no verbal feedback

c2 - giving information that the solution is incorrect (i.e., no, not that one)

c3 - encouraging to think (i.e., take a look again, think carefully)

c4 - describing solution (leads child to give the right answer, i.e., covers images and helps to guess the right answer)

c5 - gives longer explanation for solving task without observing whether the child listens or understands what has been said (monologue)

c6 - gives only one correct instruction (creates first step in scaffolding) after the child's answer gives a new step in scaffolding if necessary

c7 - gives only one correct instruction, creates first step in scaffolding, but without waiting for the child's answer, offers a new step in scaffolding

D Mother's verbal reactions after child's correct answer (correct answer is preceded by incorrect answer):

$\mathrm{d} 1$ - no verbal reactions

$\mathrm{d} 2$ - giving information that the solution is correct (i.e., yes, this one is right)

d3 - praise

d4 - more praise (bravo, bravo, great)

d5 - asking or giving extra explanation about the solution (i.e., why do you think this one is correct?)
20 arbitrary chosen video recordings have been analyzed by 2 coders (psychologists) to determine the frequency for each of the listed strategies. For the degree of adjustment of 2 coders, the Cohen kappa coefficient is 94 . Other 60 recordings have been analyzed by 1 coder, who determined the frequency for each of the listed categories.

The representation of strategies is established by placing each mother's verbal reaction into the appropriate category. Each mother's verbal reaction is then rated 1 . The data obtained this way shows the number of times each mother uses each strategy.

The following analysis establishes the representation of strategies used within each of the 4 categories (mother's verbal reactions at the beginning of each task, mother's verbal reactions when child solves task correctly, mother's verbal reactions to child's incorrect answer, and mother's verbal reactions to child's correct answer preceded by child's incorrect answer). This enabled the calculation of the representation of each verbal reaction within the categories.

\section{Procedure}

This research was described in details at a parents' meeting in 5 kindergartens in the city of Osijek, where mothers were asked to participate together with their children. As previously agreed upon at the meetings, the recording took place individually for each mother and child in appropriate rooms.

The solving of tasks by mother and child together was recorded first. Afterwards, The Manchester Child Attachment Story Task (MCAST) with a child alone was recorded.

On average, the recording time for each mother and child took approximately $45 \mathrm{~min}$ utes. 


\section{Results and Discussion}

80 children and their mothers participated in the research. There were 41 boys (51\%) and 39 girls (49\%). Regarding the form of attachment, 39 children (49\%) are coded as securely attached to their mother, and 41 children $(51 \%)$ are coded as insecurely attached to their mother. Regarding the education of the mothers, 25 mothers of securely attached children have finished secondary school, and 14 have a degree. 32 mothers of insecurely attached children have finished secondary school, and 9 mothers of insecurely attached children have a degree. Securely and insecurely attached children do not differ with regards to their mother's education $\left(\chi^{2}=.90 ; p>.05\right)$.

In order to establish if there is a difference between mothers of securely and mothers of insecurely children regarding the strategies used in helping children with problem task solving, the Mann-Whitney U test was used. Since the data was not normally distributed, non-parametric statistics were used. The

Table 1 The results of testing the significance of differences between mothers of securely attached children and mothers of insecurely attached children, regarding the mother's verbal reactions at the beginning of each problem-solving task

\begin{tabular}{|c|c|c|c|c|c|c|}
\hline \multirow[t]{2}{*}{$\begin{array}{l}\text { Mother's verbal reactions at } \\
\text { the beginning of each task }\end{array}$} & \multicolumn{2}{|c|}{$\begin{array}{l}\text { Mothers of securely } \\
\text { attached children } \\
\qquad \mathrm{N}=39\end{array}$} & \multicolumn{2}{|c|}{$\begin{array}{c}\text { Mothers of } \\
\text { insecurely attached } \\
\text { children } \\
\mathrm{N}=41\end{array}$} & \multirow[b]{2}{*}{$\begin{array}{c}\text { Mann- } \\
\text { Whitney }\end{array}$} & \multirow[b]{2}{*}{$\mathrm{p}$} \\
\hline & $\begin{array}{l}\text { Mean } \\
\text { Rank }\end{array}$ & $\begin{array}{c}\text { Sum of } \\
\text { Ranks }\end{array}$ & $\begin{array}{l}\text { Mean } \\
\text { Rank }\end{array}$ & $\begin{array}{l}\text { Sum of } \\
\text { Ranks }\end{array}$ & & \\
\hline No verbal reactions & 42.44 & 1655.00 & 38.66 & 1585.00 & 724.00 & .46 \\
\hline $\begin{array}{l}\text { Saying to child that it needs } \\
\text { to solve task (motivating, } \\
\text { encouraging) }\end{array}$ & 38.06 & 1484.50 & 42.82 & 1755.50 & 704.50 & .36 \\
\hline $\begin{array}{l}\text { Warning child to be careful } \\
\text { (i.e., look carefully, don't } \\
\text { hurry) }\end{array}$ & 38.95 & 1519.00 & 41.98 & 1721.00 & 739.00 & .55 \\
\hline $\begin{array}{l}\text { Gives only one correct } \\
\text { instruction (creates the first } \\
\text { step in scaffolding) }\end{array}$ & 39.26 & 1531.00 & 41.68 & 1709.00 & 751.00 & .63 \\
\hline $\begin{array}{l}\text { Gives longer explanation for } \\
\text { solving task without } \\
\text { observing if the child listens } \\
\text { or understands what has } \\
\text { been said (monologue) }\end{array}$ & 41.60 & 1622.00 & 39.45 & 1617.50 & 756.50 & .47 \\
\hline $\begin{array}{l}\text { Describes solution (leads } \\
\text { child to give right answer, } \\
\text { i.e., covers drawings and } \\
\text { helps child guess) }\end{array}$ & 43.54 & 1698.00 & 37.61 & 1542.00 & 681.00 & .16 \\
\hline
\end{tabular}


observed mother's reactions are the following: mother's verbal reactions at the beginning of each task, mother's verbal reactions when child solves task correctly, mother's verbal reactions to child's incorrect answer, and mother's verbal reactions to child's correct answer, which is preceded by child's incorrect answer.

The results of testing the significance of differences between mothers of securely attached children and mothers of insecurely attached children, regarding the mother's verbal reactions at the beginning of each problem-solving task, are shown in Table 1.

The results show no statistically significant differences between mothers of securely attached children and mothers of insecurely attached children regarding their verbal reactions at the beginning of the problem-solving tasks.

The results of testing the significance of differences between mothers of securely attached children and mothers of insecurely attached children, regarding the mother's verbal reactions when child solves the task correctly are shown in Table 2.

The results show no statistically significant differences between mothers of securely attached children and mothers of insecurely attached children regarding their verbal reactions when children solve the task correctly. Mothers of securely attached and

Table 2 The results of testing the significance of differences between mothers of securely attached children and mothers of insecurely attached children, regarding the mother's verbal reactions when child solves the task correctly

\begin{tabular}{|c|c|c|c|c|c|c|}
\hline \multirow{2}{*}{$\begin{array}{l}\text { Mother's verbal reactions } \\
\text { after child solves task } \\
\text { correctly (correct answer is } \\
\text { not preceded by incorrect } \\
\text { answer) }\end{array}$} & \multicolumn{2}{|c|}{$\begin{array}{c}\text { Mothers of } \\
\text { securely } \\
\text { attached children } \\
\mathrm{N}=39\end{array}$} & \multicolumn{2}{|c|}{$\begin{array}{c}\text { Mothers of } \\
\text { insecurely } \\
\text { attached children } \\
\mathrm{N}=41\end{array}$} & \multirow[b]{2}{*}{$\begin{array}{c}\text { Mann- } \\
\text { Whitney }\end{array}$} & \multirow[b]{2}{*}{$\mathrm{p}$} \\
\hline & $\begin{array}{l}\text { Mean } \\
\text { Rank }\end{array}$ & $\begin{array}{l}\text { Sum of } \\
\text { Ranks }\end{array}$ & $\begin{array}{l}\text { Mean } \\
\text { Rank }\end{array}$ & $\begin{array}{l}\text { Sum of } \\
\text { Ranks }\end{array}$ & & \\
\hline No verbal reactions & 39.36 & 1535.00 & 41.59 & 1705.00 & 755.00 & .63 \\
\hline $\begin{array}{l}\text { Confirmation that child } \\
\text { correctly solved the task } \\
\text { (i.e., yes, good) }\end{array}$ & 44.22 & 1724.50 & 36.96 & 1515.50 & 654.50 & .16 \\
\hline Praise (i.e., well done, great) & 39.45 & 1538.50 & 41.50 & 1701.50 & 758.50 & .69 \\
\hline $\begin{array}{l}\text { More praise (bravo, bravo, } \\
\text { great) }\end{array}$ & 38.97 & 1520.00 & 41.95 & 1720.00 & 740.00 & .46 \\
\hline $\begin{array}{l}\text { Asking or giving extra } \\
\text { explanation about solution } \\
\text { (i.e., why do you think this } \\
\text { one is correct?) }\end{array}$ & 41.53 & 1619.50 & 39.52 & 1620.50 & 759.50 & .53 \\
\hline
\end{tabular}


mothers of insecurely attached children do not differ in their response to the children's correct task solving.

The results of testing the significance of differences between mothers of securely attached children and mothers of insecurely attached children, regarding the mother's verbal reactions to child's incorrect response are shown in Table 3.

The results show statistically significant difference between mothers of securely attached children and mothers of insecurely attached children regarding mother's inadequate explanation given to the child when the child does not solve the problem-solving task on its own $(\mathrm{U}=661.00, \mathrm{p} \leq .05, \mathrm{r}=$ -.23). Mothers of insecurely attached children give inadequate explanations more often in comparison to the mothers of securely attached children. Mothers give long explanations, do not respond to the child's reactions, they have a monologue, i.e., they are not sensitive to the child's abilities and needs.

One of the research studies done with a sample of 40 children and mothers revealed a positive relation between the secure attachment in children aged from six on and the quality of mother's teaching (Lippe \& Crittenden, 2000; as cited in von der Lippe, Eilertsen, Hartmann, \& Killèn, 2010). Securely attached children have mothers who provide them with efficient instructions. The results of research with children up to three years of age, done by Grossmann, ScheuererEnglisch, \& Loher (1991, as cited in von der Lippe, Eilertsen, Hartmann, \& Killèn, 2010) show that parents of securely attached children exhibit non-intervening behavior and help children only when they signalize discontent during play. Statistically significant difference is also apparent when mothers give one appropriate instruction $(\mathrm{U}=555.50, \mathrm{p}<$ $.05, \mathrm{r}=-.26)$. Mothers of securely attached children give one appropriate instruction to the child, after the child does not solve the task on its own, more often in comparison to the mothers of insecurely attached children. These mothers help the child to realize what the problem is and enable him/her to continue solving it by giving minimal help and directing the child towards the solution of the task.

This kind of building of a scaffold, done by an adult during a joined activity to encourage solving of the tasks, is an important manifestation of the sensitivity to the child's aptitude for new achievement. Adult support is also important in the context of the child's effort to ask for help when necessary. In addition, this behavior encourages the child's acquisition of new skills and independent problem solving (Colman \& Thompson, 2002).

According to Stright, Herr, \& Neitzel (2009), maternal cognitive support of children's problem solving predicts children's reasoning skills in kindergarten in a way that directive instruction positively predicts children's conscientious behavior and negatively predicts children's autonomous behavior. The research done by Fagot, Gauvain, \& Kavanagh (1996) with children up to 3 years of age shows that mothers who explain steps for problem solving (giving clear instructions) are the mothers of securely attached children. Mothers of insecurely attached children have lower results in measurements of the quality of help, including not helping, as well as direct, intrusive help.

In research done with children aged 2 to 5 and their mothers, children were doing a puzzle, and mothers were instructed to offer help only if asked by children, Colman \& 
Table 3 The results of testing the significance of differences between mothers of securely attached children and mothers of insecurely attached children, regarding the mother's verbal reactions to child's incorrect response

\begin{tabular}{|c|c|c|c|c|c|c|}
\hline \multirow{2}{*}{$\begin{array}{l}\text { Mother's verbal reactions } \\
\text { after child's incorrect } \\
\text { answer }\end{array}$} & \multicolumn{2}{|c|}{$\begin{array}{c}\text { Mothers of } \\
\text { securely attached } \\
\text { children } \\
\mathrm{N}=39 \\
\end{array}$} & \multicolumn{2}{|c|}{$\begin{array}{c}\text { Mothers of } \\
\text { insecurely } \\
\text { attached children } \\
\mathrm{N}=41 \\
\end{array}$} & \multirow[b]{2}{*}{$\begin{array}{c}\text { Mann- } \\
\text { Whitney }\end{array}$} & \multirow[b]{2}{*}{$\mathrm{p}$} \\
\hline & $\begin{array}{l}\text { Mean } \\
\text { Rank }\end{array}$ & $\begin{array}{l}\text { Sum of } \\
\text { Ranks }\end{array}$ & $\begin{array}{l}\text { Mean } \\
\text { Rank }\end{array}$ & $\begin{array}{l}\text { Sum of } \\
\text { Ranks }\end{array}$ & & \\
\hline $\begin{array}{l}\text { No verbal feedback } \\
\text { information }\end{array}$ & 38.86 & 1515.50 & 42.06 & 1724.50 & 735.50 & .37 \\
\hline $\begin{array}{l}\text { Giving information that } \\
\text { solution is incorrect (i.e., } \\
\text { no, not that one) }\end{array}$ & 39.03 & 1522.00 & 41.90 & 1718.00 & 742.00 & .57 \\
\hline $\begin{array}{l}\text { Encouraging to think (i.e., } \\
\text { take a look again, think } \\
\text { carefully) }\end{array}$ & 36.77 & 1434.00 & 44.05 & 1806.00 & 654.00 & .16 \\
\hline $\begin{array}{l}\text { Describing solution (leads } \\
\text { child to give right answer, } \\
\text { i.e., covers images and } \\
\text { helps to guess the right } \\
\text { answer) }\end{array}$ & 41.23 & 1608.00 & 39.80 & 1632.00 & 771.00 & .78 \\
\hline $\begin{array}{l}\text { Gives longer explanation } \\
\text { for solving task without } \\
\text { observing if the child } \\
\text { listens or understands what } \\
\text { has been said (monologue) }\end{array}$ & 36.95 & 1441.00 & 43.88 & 1799.00 & 661.00 & $.05^{*}$ \\
\hline $\begin{array}{l}\text { Gives only one correct } \\
\text { instruction (creates first } \\
\text { step in scaffolding) after } \\
\text { child's answer gives new } \\
\text { step in scaffolding if } \\
\text { necessary }\end{array}$ & 46.76 & 1823.50 & 34.55 & 1416.50 & 555.50 & $.02 *$ \\
\hline $\begin{array}{l}\text { Gives only one correct } \\
\text { instruction, creates first } \\
\text { step in scaffolding, but } \\
\text { without waiting for child's } \\
\text { answer, offers new step in } \\
\text { scaffolding }\end{array}$ & 38.19 & 1489.50 & 42.70 & 1750.50 & 709.50 & .25 \\
\hline
\end{tabular}


Thompson (2002) concluded that the mothers with lower results on the scale of secure attachment do not encourage the children during problem-solving tasks as much as the mothers with higher results on the scale of secure attachment. Consequentially, securely attached children approach problemsolving tasks with greater confidence and efficacy than insecurely attached children.

The results of testing the significance of differences between mothers of securely attached children and mothers of insecurely attached children, regarding mother's verbal reactions to child's correct response preceded by an incorrect response is shown in Table 4.
The results show statistically significant difference between mothers of securely attached and mothers of insecurely attached children, regarding the mother's refraining from verbal response when the child answers correctly after the first or several incorrect answers $(\mathrm{U}=558.00, \mathrm{p} \leq .01, \mathrm{r}=-.29)$. Mothers of insecurely attached children more often refrain from verbal response when the child answers correctly after the first or several incorrect answers, as compared to the mothers of securely attached children. Response and praise have a motivating effect and are particularly important when the child makes an additional effort to solve a task that could not be solved at first. In these

Table 4 The results of testing the significance of differences between mothers of securely attached children and mothers of insecurely attached children, regarding mother's verbal reactions to child's correct response preceded by an incorrect response

\begin{tabular}{|c|c|c|c|c|c|c|}
\hline \multirow{2}{*}{$\begin{array}{l}\text { Maternal strategies in } \\
\text { cases of child's correct } \\
\text { response after one or more } \\
\text { incorrect attempts }\end{array}$} & \multicolumn{2}{|c|}{$\begin{array}{c}\text { Mothers of } \\
\text { securely } \\
\text { attached children } \\
\mathrm{N}=39\end{array}$} & \multicolumn{2}{|c|}{$\begin{array}{c}\text { Mothers of } \\
\text { insecurely } \\
\text { attached children } \\
\mathrm{N}=41\end{array}$} & \multirow[b]{2}{*}{$\begin{array}{l}\text { Mann- } \\
\text { Whitney }\end{array}$} & \multirow[b]{2}{*}{$\mathrm{p}$} \\
\hline & $\begin{array}{l}\text { Mean } \\
\text { Rank }\end{array}$ & $\begin{array}{l}\text { Sum of } \\
\text { Ranks }\end{array}$ & $\begin{array}{l}\text { Mean } \\
\text { Rank }\end{array}$ & $\begin{array}{c}\text { Sum of } \\
\text { Ranks }\end{array}$ & & \\
\hline No verbal feedback & 34.31 & 1338.00 & 46.39 & 1902.00 & 558.00 & $.01 * *$ \\
\hline $\begin{array}{l}\text { Confirming the correctness } \\
\text { of the child's response }\end{array}$ & 43.31 & 1689.00 & 37.83 & 1551.00 & 690.00 & .29 \\
\hline Praising the child & 39.45 & 1538.50 & 41.50 & 1701.50 & 758.50 & .66 \\
\hline Giving repeated praise & 40.00 & 1560.00 & 40.98 & 1680.00 & 780.00 & .57 \\
\hline $\begin{array}{l}\text { Asking the child to } \\
\text { elaborate on the answer } \\
\text { and giving additional } \\
\text { explanations of the answer } \\
\text { herself }\end{array}$ & 40.51 & 1580.00 & 40.49 & 1660.00 & 799.00 & .10 \\
\hline
\end{tabular}


situations, the mothers of insecurely attached children are not sensitive to the additional effort the child makes nor do they give recognition to the child that the task is correctly solved.

Regarding the resulting differences between mothers of securely attached children and mothers of insecurely attached children, in their ways of helping the children during problem-solving tasks, and with regard to the importance of mother's providing scaffolding for the child's development, it would be useful to establish if insecurely attached children are at risk for developing less effective strategies when dealing with cognitive demands, besides being at risk for developing behavioral problems. In addition, recordings analyzed this way enable us to instruct the mothers in the appropriate ways of helping their children during problem-solving tasks.

\section{Conclusions}

In the attachment theory it is said that mother's behavior (foster parent's behavior) is the key element in establishing and maintaining a child's attachment behavior during their childhood. This unequal relationship develops and represents a continual challenge, which demands of the mother to adapt to each developmental stage of her child (Moss, Cyr, \& Dubois-Comtois, 2004).

Besides the affective needs of the child, the parent also responds to his/her cognitive needs. In order to establish the difference between mothers of securely attached children and mothers of insecurely attached children in situations when a child has a cognitive problem, the mother's verbal reactions were tested during the child's problem solving. The results show that mothers of se- curely attached children, in a situation when a child is solving a problem and gives an incorrect answer more often help the child solve the task by giving one appropriate instruction (they build the first step of a scaffolding), compared to the mothers of insecurely attached children. The behavior of mothers of securely attached children is sensitive, they understand the strategy they use to help the child, and adapt it to the necessary amount of information, which is then given to the child.

This result is compatible with the results of our research, which show the difference between mothers of securely attached children and mothers of insecurely attached children in a situation when a child does problem-solving tasks and gives an incorrect answer. Mothers of insecurely attached children help their children more often by giving a long explanation (monologue) without noticing whether the child listens or understands what is being said. Compared to the mothers of securely attached children, mothers of insecurely attached children tend to give long explanations, do not follow the child's reactions, have a monologue, i.e., they are not sensitive to the child's abilities and needs. The research also shows that mothers of insecurely attached children do not verbally respond to the child's correct problem solving, after their first or multiple incorrect attempts, as often as mothers of securely attached children.

Received February 10, 2014

\section{References}

Baucal, A. (2003). Konstrukcija i ko-konstrukcija u zon i naprednog razvojna: da li Pijaže i Vygotski mogu biti u pravu? Psihologija, 36(4), 517-542. doi:10.2298/PSI0304517B 
Belsky, J., Rovine, M., \& Taylor, D. G. (1984). The Pennsylvania infant and family development project, III: The origins of individual differences in infant mother attachment: Maternal and infant contributions. Child Development, 55(3), 718-728.

Bowlby, J. (1969/1982). Attachment and loss: Vol. 1. Attachment. New York: Basic Books.

Colman, R., \& Thompson, R. A. (2002). Attachment status, adaptive functioning, and problemsolving interaction styles in mother-child dyads. Merrill-Palmer Quarterly, 48, 337-359.

Etzion-Carasso, A., \& Oppenheim, D. (2000). Open mother-pre-schooler communication: Relations with early secure attachment. Attachment \& Human Development, 2(3), 347-370. doi: $10.1080 / 14616730010007914$

Fagot, B. I., Gauvain, M., \& Kavanagh, K. (1996). Infant attachment and mother-child problem solving: A replication. Journal of Social and Personal Relationships, 13(2), 295-302. doi: 10.1177/0265407596132008

George, C., \& Solomon, J. (2008). The measurement of attachment security and related in infancy and early childhood. In J. Cassidy, \& P. R. Shaver (Eds.), Handbook of attachment: Theory, research and clinical applications (pp. 383-416). New York: Guilford Press.

Green, J., Stanley, C., Smith, V., \& Goldwyn, R. (2000). A new method of evaluating attachment representations in young school-age children: The Manchester Child Attachment Story Task. Attachment and Human Development, 2(1), 48 70. doi: 10.1080/146167300361318

Ignjatović-Savić, N., Kovač-Cerović, T., Plut, D., \& Pešikan, A. (1990). Socijalna interakcija u ranom detinjstvu i njeni razvojni učinci. Psihološka istraživanja, 4, 9-70.

Main, M., \& Solomon, J. (1986). Discovery of an insecure disorganized/disoriented attachment pattern: Procedures, findings and implications for the classification of behavior. In T. Brazelton, \& M. Yogman (Eds.), Affective development in in- fancy (pp. 95-124). Westport, CT, US: Ablex Publishing.

Moss, E., Cyr, C., \& Dubois-Comtois, K. (2004). Attachment at early school age and developmental risk: Examining family contexts and behavior problems of controlling caregiving, controlling-punitive, and behaviorally disorganized children. Development Psychology, 40(4), 519-532. doi: 10.1037/0012-1649.40.4.519

Nievar, M. A., \& Becker, B. J. (2008). Sensitivity as a privileged predictor of attachment: A second perspective on De Wolff and van IJzendoorn's meta-analysis. Social Development, 17(1), 102114. doi: 10.1111/j.1467-9507.2007.00417.x

Posada, G., Kaloustian, G., Richmond, M. K., \& Moreno, A. J. (2007). Maternal secure base support and preschoolers' secure base behavior in natural environments. Attachment \& Human Development, 9(4), 393-411. doi: 10.1080/ 14616730701712316

Raven, J., Raven, J. C., \& Court, J. H. (1999). Priručnik za Ravenove progresivne matrice $i$ ljestvice rječnika, standardne progresivne matrice. Jastrebarsko: Naklada Slap.

Stright, A. D., Herr, M. Y., \& Nietzel, C. (2009). Maternal scaffolding of children's problem solving and children's adjustment in kindergarten: Hmong families in the United States. Journal of Educational Psychology, 101(1), 207-218. doi: 10.1037/a0013154

Vasta, R., Heith, M., \& Miller, S. A. (1998). Dječja psihologija. Jastrebarsko: Naklada Slap.

Vizek Vidović, V., Rijavec, M., Vlahović-Štetić, V., \& Miljković, D. (2003). Psihologija Obrazovanja. Zagreb: IEP.

von der Lippe, A., Eilertsen, D. E., Hartmann, E., $\&$ Killèn, K. (2010). The role of maternal attachment in children's attachment and cognitive executive functioning: A preliminary study. Attachment \& Human Development, 12(5), 429444. doi: 10.1080/14616734.2010.501967

Vygotski, L. (1977). Mišljenje i govor. Beograd: Nolit. 


\title{
METÓDY, KTORÝMI MATKY POMÁHAJÚ ĎEŤOM RIEŠIŤ KOGNITÍVNE ÚLOHY: \\ POROVNANIE MATIEK S PEVNOU A SLABOU VZŤAHOVOUVÄZBOU K SVOJIM PREDŠKOLSKÝM DEŤOM
}

\author{
L. C a k i ć, L. M a r j a n o vi č - U m e k
}

Súhrn: Vzt’ahová väzba je ustálená emočná väzba aktivovaná signálmi, ktoré deti vnímajú ako strašidelné, nebezpečné alebo stresujúce, zatial' čo v systéme rodičovskej starostlivosti je aktivovaná cielom uspokojit' potreby detí. Zámerom výskumu bolo určit', aké stratégie využívajú matky pri kontakte s det'mi vo veku 5 až 7 rokov $(\mathrm{n}=80)$ počas riešenia kognitívnych problémov. Presnejšie povedané, ciel'om výskumu bolo zistit', či existuje rozdiel v citlivosti na kognitívne potreby diet’ata u matiek s pevnou a so slabou vzt’ahovou väzbou. V porovnaní s matkami, ktoré majú so svojimi det’mi slabú vzt’ahovú väzbu, matky s pevnou vzt'ahovou väzbou diet'at’u často pomáhajú prostredníctvom vhodných inštrukcií ("stavba lešenia"). V situáciách ked' diet’a dospeje k nesprávnemu riešeniu, matky so slabou vzt’ahovou väzbou často poskytnú det’om siahodlhé vysvetlenia, bez ohl'adu na to, či diet’a počúva alebo rozumie, čo sa mu hovorí (monológ). 